Александра Корда-Петровић

Универзитет у Београду

Филолошки факултет

Катедра за славистику

korda@verat.net
УДК 81 255.4:821.162.3-1(=163.41) https://doi.org/10.18485/slavistika.2021.25.1.6

Оригинални научни рад примљено 13.01.2021.

прихваћено за штампу 17.06.2021.

\title{
ПЕСМЕ ЈАРОСЛАВА САЈФЕРТА У ПРЕВОДУ МИОДРАГА СИБИНОВИЋА
}

У раду се представља избор од десет песама чешког нобеловца Јарослава Сајферта који је објављен у преводу професора Миодрага Сибиновића у часопису Мостови 1985. године. Уз анализу превода појединих стихова и њихово поређење са другим постојећим верзијама превода, главна интенција рада је да се укаже на знање, вештину и песнички таленат преводиоца.

Кључне речи: Миодраг Сибиновић, превод поезије, Јарослав Сајферт.

The work presents a selection of ten poems of Czech Nobel Prize recipient Jaroslav Sajfert, which was published in the translation of Professor Miodrag Sibinovic in the Mostovi journal in 1985. Along with the analysis of translation of some verses and their comparison with other existing versions of the translation, the principal intention of the work is to point out the knowledge, skill and poetic talent of the translator.

Keywords: Miodrag Sibinović, translation of poetry, Jaroslav Sajfert.

Добро је познато да је део научног рада професора Миодрага Сибиновића (1937-2020) био посвећен теорији књижевног превођења. Његове књиге Оригинал и превод (1979), Нови оригинал (1990), Нови живот оригинала (2009), као и уџбеници О превођењу. Приручник за преводиоче и инокоресподенте (1983) и Техника превођења (1990) данас представљају незаобилазну литературу за све оне који се баве превођењем, а пре свега за оне који се баве књижевним превођењем. Свеобухватни и стручни приступ теорији и пракси књижевног превођења утемељен је на ауторовом научном и преводилачком искуству. Као историчар књижевности компаратистичке оријентације и професор руске књижевности на Филолошком факултету у Београду, у свом научном раду Миодраг Сибиновић бавио се анализом књижевних дела источнословенских и српских аутора, као и рецепцијом њихових дела у српској средини. Тиме је незаобилазни сегмент ових истраживања била и анализа књижевних превода. Као књижевни преводилац, превео је на српски језик хиљаде стихова и низ прозних дела из руске, белоруске, украјинске, бугарске, јерменске и грузијске књижевности. Приредио је више избора превода источнословенских аутора, као и антологије руске, белоруске и украјинске поезије. За свој преводилачки рад добио је више међународних и домаћих награда и признања. ${ }^{1}$

\footnotetext{
${ }^{1}$ Миодраг Сибиновић носилац је награде „Милош Ђурић“ (1999), украјинске међународне награде „Иван Франко“, награде за најбољи превод руске књижевне прозе „Др. Јован Максимовић“ (2002) и Награде за животно дело Удружења књижевних преводилаца Србије (2004).
} 
Мање је познато да се у ризници књижевних превода професора Миодрага Сибиновића налазе и преводи стихова чешког песника Јарослава Сајферта (Jaroslav Seifert, 1901-1986), добитника Нобелове награде за књижевност. Реч је о песнику који с правом носи епитет „највећи чешки лиричар 20. века“. У својој песничкој поетици прошао је пут од надахнутог песника пролетерске поезије, преко поетистичке фазе коју је делио са осталим чешким песницима, члановима Уметничког савеза Девјетсил 20-их година 20. века, па до зрелог периода свога стваралаштва, када формира посебан индивидуални лирски песнички стил. Током живота објавио је преко двадесет збирки песама и две књиге белетризованих успомена. ${ }^{2}$ Ипак, у српској и југословенској средини међуратног и поратног периода, поезија Јарослава Сајферта у малој мери је била позната. По неколико преведених Сајфертових песама нашло се у антологијама чешке поезије, као што су Модерна чешка лирика (Београд, 1930) у преводу Јована Кршића, Звона сунща и гробова (Загреб, 1958) у преводу Миодрага Ашанина и у антологији Савремена чехословачка поезија (Београд, 1962) у избору и преводу Јаре Рибникар и Десанке Максимовић. ${ }^{3}$ Тек када је чешки песник добио Нобелову награду за књижевност 1984. године, објављено је посебно издање избора из Сајфертове поезије под називом Изабране песме (Београд, 1984), у избору и преводу Јаре Рибникар и Ивана Л. Лалића. Убрзо затим у часопису за преводну књижевност Удружења књижевних преводилаца Србије Мостови (јануар - март 1985) биће објављено десет песама Јарослава Сајферта у преводу професора Миодрага Сибиновића.

У истом броју часописа Мостови био је објављен текст професора Драгутина Мирковића под називом „На раскршћу између пролетерске поезије, поетизма и традиционализма“, са поднасловом „Поглед на поетику Јарослава Сајферта“ (Мостови, год. XVI, свеска 1(6), бр. 61, стр. 8-15). Уколико изузмемо поговор у поменутом посебном издању Српске књижевне задруге (Јарослав Сајферт: Изабране песме, Београд 1984), који је написала Јара Рибникар у есејистичком тону, овај текст је у нашој средини био прва опсежнија студија посвећена целокупном делу чешког нобеловца. Из пера Драгутина Мирковића (1921-1998), врсног познаваоца чешке књижевности, редовног професора Филолошког факултета у Београду, наша јавност је први пут имала прилику да сагледа укупно дело Ј. Сајферта из перспективе савремене књижевне историје. Студиозно, хронолошко и синтетичко сагледавање свих фаза песниковог поетског развоја у овом тексту праћено је детаљном анализом одабраних стихова из више Сајфертових збирки песама. За ту прилику било је нужно превести одабране примере, те је у једној од првих фуснота овог текста наглашено да су сви стихови из наведених песама препеви проф. др Миодрага Сибиновића.

Из личног сведочења два професора познато нам је да је њихова сарадња на овом послу била природни резултат подударних научних и истраживачких напора у области словенске поезије. Професор Миодраг Сибиновић је тада већ имао довољно преводилачког искуства, а професор Драгутин Мироковић је

\footnotetext{
${ }^{2}$ Једну од њих, под називом Све лепоте света (V̌̌ecky krásy světa) превео је Милан Чолић и објављена је у издању „Дечјих новина“ (Горњи Милановац 1988).

${ }^{3} \mathrm{O}$ томе више у Корда-Петровић 2013.
} 
био уверен да је одабрао за сарадника на овом послу доброг зналца песничког умећа, али пре свега преводиоца са талентом за писање поезије. За успешно превођење Сајфертове поезије, више од познавања језика оригинала, био је потребан „песнички осећај“. Захваљујући овом коауторском раду, у оквиру кога je, претпостављамо, Д. Мирковић „грубо“ преводио значење песама са чешког на српски језик, а М. Сибиновић препевавао и уобличавао преводе Сајфертових стихова, пред нама је још једна варијанта „читања“ песникове поезије. Такође, овим преводом се професор Сибиновић придружио кругу преводилаца који су се ухватили у коштац са поетичном и мелодичном лириком чешког песника. ${ }^{4}$

$* * *$

Избор од десет песама из четири збирке песама Јарослава Сајферта у преводу Миодрага Сибиновића у часопису Мостови насловљен је једноставно „Песме“. Прве две песме „Говор гомиле“ (Řeč davu) и „Грешни град“ (Hř́šné město) преведене су из прве песникове збирке Град у сузама (Město v slzách, 1921). Ова збирка сматра се за пример прве фазе Сајфертовог песништва, припада периоду када је он под утицајем прокламованих принципа авангардне чешке групе „Девјетсил“ и када пише тзв. пролетерску поезију, преносећи ново заједничко социјално виђење света. Тој збирци Драгутин Мирковић у поменутом тексту „На распућу између пролетерске поезије, поетизма и традиционализма“" посвећује прве странице. Како би објаснио разлику између Сајфертовог доживљаја социјалне неправде и улоге пролетаријата у односу на друге песнике овог правца, Д. Мирковић посебно издваја песникову „спонтаност опредељења и поистовећивања“" (Мирковић 1985: 9), као и чињеницу да се у песниковој „једноставности крије често и свесна аутостилизација“ (Мирковић 1985: 10), а како би то и доказао цитира две од три строфе песме „Говор гомиле“ у преводу М. Сибиновића. Песма одише бунтом, новом енергијом, наивном надом у револуцију и испевана је попут корачнице, кратким стиховима који углавном започињу заменицом „ми“. Тиме се преноси идеја о заједништву, колективу, снази радничке класе. У преводу је успешно дочарана ритмичност песме, доследно се преноси неправилна рима, чиме се дочарава представа снаге и моћи гомиле: ,...Ми смо гомила/ ми смо пламен што из кратера кульне/ што ће нарасти/ у огромни пожар снаге и страсти/ми смо таме/ с крицима муња што потмуло грме/ми смо петарда гнева што у одсудном часу прасне/ ми смо маса..." (Сајферт 1985: 16).

У овом избору чак пет песама је из збирке Свадбени пуm (Svatební cesta, 1938), ${ }^{5}$ од којих само једну под називом „Дим од цигарете“ анализира Д.

${ }^{4}$ Осим поменутих преводилаца (Јована Кршића, Миодрага Ашанина, Јаре Рибникар, Десанке Максимовић и Ивана Л. Лалића), нешто касније ће Сајфертову поезију преводити и професор Александар Илић (в. Сајферт 1996, 2014). У новијој српској периодици наилазимо на спорадичне преводе Сајфертових стихова које потписују, нпр., Светислав Костић, Лепота Кузмановић и други.

${ }_{5}^{5}$ Ова збирка Ј. Сајферта носила је назив На таласима бежичне телеграфије (Na vlnách TSF, 1925) да би у свом другом издању променила назив према поднаслову посебног дела првог издања. 
Мирковић у свом тексту као пример поетистичке фазе Сајфертовог песништва. Док се анализа Д. Мирковића фокусира на примењени принцип асоцијације као својеврсно средство организације цитиране песме и утисак готово потпуног одсуства логичке везе између садржине појединих стихова, што Д. Мирковић тумачи као једну од одлика поетистичке поезије, нас интересује у коликој мери је превод успео да пренесе целокупни уметничко-естетски ефекат песме. Код низа неповезаних асоцијација које спаја само слика уздизања дима од цигарете, преводилац чува значење у што већој мери, али ради постизања риме служи се одступањима у вези са редоследом стихова или примењује различите типове инверзија. Стихове у оригиналу: „...dým od cigarety / stoupá / turista v Alpách / slunce a hloubka // nad sráznou strží / vrcholek Montblanc / akrobacie růži / z oblak..." (Seifert 1989: 233), преводи као: „...дим од циигаре/ вине/ алпске планинаре/ сунце и дубине// понад литицуа/ Монблан се пружа/ а од облака/ акробације ружа..." (Сајферт 1985: 18). Уколико прихватимо тумачење да је песник овде применио методу „поетизовања предмета“, насупрот уобичајеном опису, те визуелним сликама прави аналогије емотивним и физиолошким стањима која повезује са представом уздузања дима од цигарете (Götz 2014: 31), примећујемо да је преводилац успео да повеже песникове представе у целину. Песма је у оригиналу лишена граматичко-логичног тока говора, док се у преводу формира целовита песничка представа. У преводу је сачувана рима и одсуство интерпункције, као што је то у изворнику. Тиме се адекватно преноси ритам песме, а применом инверзије унутар стихова очуван је највећи степен смисаоне еквивалентности.

Познато је да је професор М. Сибиновић у свом изучавању теорије и праксе превођења највише заступао тезу о функционалној еквивалентности у књижевном превођењу уопште, али и у поезији, ослањајући се између осталог на размишљања чешког теоретичара превођења Јиржија Левог (Сибиновић 2009: 217). У једном од својих радова написао је: „У савременој теорији утврђено је да је превођење књижевних дела један облик књижевног стварања. Разуме се, то се не односи на свако превођење (рецимо, не односи се на дословно, тзв. филолошко превођење поезије). Односи се на превођење којим се, уз предметно-логичке, у књижевности друге културно-језичке средине, средствима и језичким потенцијалом културе и књижевности примаоца, у највећој могућој мери - претачу све битне компоненте естетске вредности оригинала.“ (Сибиновић 2013: 263)

Управо због оваквог става преводи поезије Миодрага Сибиновића увек представљају транслатолошку рефлексију у великој мери обојену његовим песничким осећајем. То се добро види на примеру превода Сајфертове песме „Лепеза“ (Vějíř), која припада збирци Свадбени пут и која се налази у разматраном избору превода. Исту песму превео је и Миодраг Ашанин у оквиру антологије чешке поезије Звона сунща и гробова (1958) изокренувши њен назив у „Азапел“. Ради поређења наводимо ову кратку песму у оригиналу и два поменута превода: 
Vějiřr

Ukrývati dívčí ruměnec, koketní oči, hluboký vzdech, nakonec trpký úsměv a vrásky.

Motýl sedící na ňadrech, paleta lásky s barvami zašlých vzpomínek. (Seifert 1989: 120)
Азепел

Скривати дјевојачко руменило, кокетне очи, дубоки уздах На крају горки осмијех и боре лица.

Лептир што сједи на њедрима, палета љубави с бојама одлисталих успомена Превод М. Ашанин (Саjферт/Ašanin 1958: 112)

\author{
Лепеза \\ Да се заклони девојачке румени промена, \\ кокетне очи, уздах што прса надима, \\ али и горак осмех, и бора кад се јави. \\ Лептир што стоји на недрима, \\ палета љубави \\ с бојама минулих спомена.
}

Превод М. Сибиновић (Сајферт 1985: 19)

Примећујемо да у оба превода је очуван општи семантички и семантичкостилски карактер песме, а посебно у првој строфи где М. Сибиновић прибегава допуни, надоградњи песничке слике. Тако у другом стиху прве строфе уместо „дубоки уздах“, како преводи дословно Ашанин, додаје „уздах што прса надима“", што сликовитије допуњава сцену дубоког уздаха који надима девојачка прса. Ово и друга одступања преводилац користи у намери да појача путеност и осећање сете, што је свакако одлика ове Сајфертове песме. Ово је пример преводилачке креативности и слободе, исто као што је Ашанин у преводу назива песме, изокренувши реч „лепеза“, желео да нагласи одраз у огледалу, јер се лирски субјект у огледалу огледа.

Преводећи Сајфертове стихове М. Сибиновић се увек придржава метричког обрасца оригинала и у великој мери поштује изворну семантику, док одступања у сфери лексике и граматике примењује ради дочаравања мелодичности и лирске обојености песничких слика. Дакле, преводилац комбинује принципе дословног и слободног превођења, јер ,...прави преводилац је у додиру са неким новим књижевним делом увек креатор, увек стваралац који у свој рад укључује елементе поступка аналитичара књижевног дела (књижевног критичара, теоретичара, најчешће и историчара књижевности) да би, полазећи од своје конкретизације изворника, уметничким поступком, свој превод новим језичким средствима уобличио у дело које ће и сазнајном и естетском страном бити по снази приближно једнако уметнички живом изворнику.“ (Сибиновић 2009: 221)

У поменутом тексту Драгутина Мирковића посвећеног поетици Ј. Сајферта, као пример песникове позне поетистичке фазе, у којој се одриче претходно доминантног слободног стиха са неправилним римама и подређује се свим законима везаног слога са правилном строфиком, као и слабљењу метафоричности уз изразиту мелодичност (Мирковић 1975: 14), издваја пример стихова из збир- 
ке Поштански голуб (Poštovní holub, 1929). Управо из ове збирке М. Сибиновић превео је две песме „Вино авантуре“ (Víno dobrodružství) и „Песма“ (Рíseň). Интересантно је да стихови „Песме“ постоје у још два превода: у преводу М. Ашанина (у антологији Звона сунца и гробова), као и у коауторском преводу Десанке Максимовић и Јаре Рибникар (у антологији Из савремене чехословачке поезије). У коликој мери превод поезије зависи од личног песничког осећаја и тумачења преводиоца, може послужити пример превода последњег стиха ове песме у све три варијанте превода. Оригиналне стихове „Setři si slzy / a usměj se uplakanýma očima, /každého dne se néco počíná,/ něco překrásného se počíná.“ (J. Seifert 1989: 169), М. Ашанин преводи: „Обриши сузе/ и насмијеши се заплаканим очима, / сваки дан нешто се догађа,/ нешто се прелијепо рађа. “, тандем Д. Максимовић и Ј. Рибникар: „Обриши сузе,/ насмеј се уплаканим очима,/ сваког дана нешто почима,/ нешто прекрасно почима. “, док у преводу М. Сибиновића читамо: „Обриши сузе,/ осмехом смени туге очиње,/ свакога дана нешто почиње,/ нешто лепо почиње.“ У сва три превода очувана је значењска садржина стихова, ипак свако од преводилаца тражи своја решења како би сачували ритмичку и еуфонијску структуру стиха и пренели риму. Ипак, Ашанин делимично мења значење у рими „догађа-рађа“, јер Сајферт подвлачи два пута значење „почињати“. Д. Максимовић и Ј. Рибникар то поштују, али ради риме са претходним стихом „уплаканим очима“, користе архаизам „почима“, који у овом случају звучи изнуђено. Да би то избегао, М. Сибиновић прибегава другој врсти преводилачке слободе и други стих „насмеј се уплаканим очима“ преводи као „осмехом смени туге очиње“. То се у потпуности уклапа у Сибиновићев став да књижевни преводилац треба да тражи „приближне по вредности надокнаде (еквиваленти и супститути)“ (Сибиновић 2009: 2018), а све у оквирима адекватног преношења идејно-сазнајног садржаја.

Још две Сајфертове песме из овог избора превода Миодрага Сибиновића налазимо у посебном издању песникове поезије Изабране песме (Београд, 1984), у преводу Јаре Рибникар и Ивана В. Лалића. Реч је о песмама „Стопут ништа“ (Stokrát nic) из збирке Јабука са крила (Jablko z klína, 1933) и „Вечерња светла“ (Večerní světla) из збирке Свадбени пуm (Svatební cesta, 1938). Поређењем превода долазимо до сличних закључака: у оба превода очуване су смисаона еквивалентност и метричке карактеристике изворника, али у самој конкретизацији песникових мисли и емоционалног утиска песме, дајемо предност преводима М. Сибиновића. Дискретним преводилачким интервенцијама М. Сибиновић успева да „омекша“ мелодику Сајферових песама и тиме адекватније пренесе милозвучност његове лирике, као што је то у првој строфи песме „Вечерња светла“. 6 У преводу Ј. Рибникар и Ивана В. Лалића они гласе: „У којем речнику, на којој страници/ да нађем нежне речи љубави,/ кад нисам песник, а ево ноћи/ на светлој сребрној раскрсници“. У преводу М. Сибиновића исти стихови звуче овако: „У којем речнику, у којим ли књигама/ да нежне речи љубави откријем,/ јер нисам песник а ноћ је већ стигла/ на раскршће које сребрни сјај лије.“

У прилог чињеници да се М. Сибиновић у ово мало примера „огледао“ са

${ }^{6}$ Назив песме је другачији у преводу Ј. Рибникар и Ивана В. Лалића и гласи „Вечерње светлости“. 
скоро свим осталим нашим преводиоцима Сајфертових стихова, говори и пример превода последњих стихова Сајфертове песме из збирке Стуб куге (Morový sloup, 1981), који су у поменутом тексту послужили проф. Д. Мирковићу као илустрација послење фазе песниковог стваралаштва. М. Сибиновић је за ту прилику превео само завршни део последње строфе песме „На једном од својих давних путовања“, коју ће тек доста касније у целости превести Александар Илић у оквиру посебног издања превода збирке Сmуб куге (Београд, 2014). ${ }^{7}$

Вреди напоменути још једну чињеницу: иако се ради о избору који чини свега десет превода песама Ј. Сајферта, а међу њима има и песама које су са чешког превели и други врсни преводиоци, неке од њих данас можемо читати само

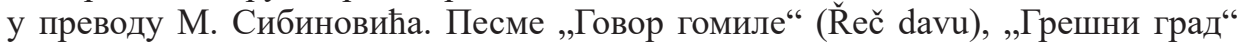
(Hříšné město), „Дим од цигаре“ (Dým cigarety), „Љубав“ (Láska), „Филозофија“ (Filozofie) и „Вино авантуре“ (Víno dobrodružství), у преводу на српски језик постоје само у оквиру овог избора објављеног у часпису Мостови. Све оне припадају првој и другој фази песниковог стваралаштва и преведене су из збирки које су у Чехословачкој биле објављене у међуратном периоду, периоду када Јарослав Сајферт стоји у строју чешке књижевне авангарде, док истовремено развија посебан тип чешке рефлексивне лирике.

Већ смо указали на околност да се професор Миодраг Сибиновић латио превођења Сајфертове поезије у оквиру сарадње са професором Драгутином Мирковићем, а у намери да у часопису Мостови, свако на свој начин, представе до тада мало познату поезију чешког песника који је у то време добио Нобелову награду за књижевност. Успешни преводи стихова Јарослава Сајферта, који су били резултат ове сарадње, потврдили су да је добар књижевни аналитичар, познавалац теорије и праксе књижевног превођења и искусни преводилац поезије са источнословенских језика, могао да се избори са изазовом превођења стихова изразитог лиричара и то са чешког језика, са кога до тада није преводио. Поред знања и искуства, можда најважнији фактор успешности ових превода видимо у песничком таленту самог преводиоца, који је слободним преводилачким интервенцијама успео да пренесе дух и лепоту поезије Јарослава Сајферта.

\section{Цитирана литература}

Корда-Петровић, Александра. „Преплитање два песничка света - Десанка Максимовић и Јарослав Сајферт“. [У:] С. Тутњевић (ур.) Над целокупним делом Десанке Максимовић. Београд: Задужбина „Десанка Максимовић“, 2013, 309-321.

${ }^{7}$ Александар Илић на крају свог избора и превода Сајфертове збирке Morový sloup, у „Напомени о преводу“, објашњава због чега је наслов збирке превео као Стуб куге, а не као Споменик куги (како је наведено у тексту Д. Мирковића и кратком одломку превода М. Сибиновића). Иако се то у Илићевој напомени не наводи, јасна је полемика са другим преводиоцем: „Збирку сам превео као стуб куге, а не споменик куге. Најпре: на чешком се стуб каже sloup, како то вели Сајферт, а споменик је роmnik. Затим: стуб симболизује вертикалу од куге ка љубави и вечном животу. Споменик може да буде и коцкаст. И на крају, то не би био Сајферт када сам не би казао да његова збирка не опева само метафизику смрти већ и љубав. Стуб куге је и место љубавних састанака...“. (Ilić 2014: 95). 
[Korda-Petrović, Aleksandra. "Preplitanje dva pesnička sveta - Desanka Maksimović i Jaroslav Sajfert". [U:] S. Tutnjević (ur.) Nad celokupnim delom Desanke Maksimović. Beograd: Zadužbina „Desanka Maksimović“, 2013, 309-321]

Мирковић, Драгутин. „На распућу између пролетерске поезије, поетизма и традиционализма. Поглед на поетику Јарослава Сајферта“. Мостови 16, 1985: 8-15.

[Mirković, Dragutin. "Na raspuću između proleterske poezije, poetizma i tradicionalizma. Pogled na poetiku Jaroslava Sajferta“. Mostovi 16, 1985: 8-15]

Сибиновић, Миодраг. Нови живот оригинала. Београд: Просвета, Алтера, УСНПС, 2009.

[Sibinović, Miodrag. Novi život originala. Beograd: Prosveta, Altera, USNPS, 2009]

Сибиновић, Миодраг. "Над издањем целокупних дела Десанке Максимовић. Могућности за даље проучавање живота и дела Десанке Максимовић на грађи њених превода, есеја и путописа“. [У:] С. Тутњевић (ур.) Над целокупним делом Десанке Максимовић. Београд: Задужбина „Десанка Максимовић“, 2013, 261-273.

[Sibinović, Miodrag. "Nad izdanjem celokupnih dela Desanke Maksimović. Mogućnosti za dalje proučavanje života i dela Desanke Maksimović na građi njenih prevoda, eseja i putopisa“. [ In:] S.Tutnjević (ur.) Nad celokupnim delom Desanke Maksimović. Beograd: Zadužbina „Desanka Maksimović“, 2013, 261-273]

Götz, František. „Jaroslav Seifert“. [ In:] J. Flaišman (ed.) Čtení o Jaroslavu Seifertovi. Hledání proměn autorovy poetiky. Praha: Insitut pro studium literatury, 2014, 22-32.

Ilić, Aleksandar. „Napomena o prevodu“. [ In:] Sajfert, Jaroslav. Stub kuge. Beograd: Mali vrt, 2014.

\section{Извори}

Сајферт, Јарослав. „Песме“. Мостови 16, 1985: 16-20.

[Sajfert, Jaroslav. „Pesme“. Mostovi 16, 1985: 16-20]

Сајферт, Јарослав. Изабране песме. Београд: Српска књижевна задруга, 1984.

[Sajfert, Jaroslav. Izabrane pesme. Beograd: Srpska književna zadruga, 1984]

Сајферт, Јарослав. „Кишобран с Пикадилија“. Поезија 2, октобар 1996, 69-80.

[Sajfert, Jaroslav. „Kišobran s Pikadilija“. Poezija 2, oktobar 1996, 69-80]

Сајферт, Јарослав. Стуб куге. Београд: Мали врт, 2014.

[Sajfert, Jaroslav. Stub kuge. Beograd: Mali vrt, 2014]

Sajfert, Jaroslav. „Azepel“. [ In:] Ašanin, Miodrag. Zvona sunca i grobova. Zagreb: Lykos, 1958, 112.

Sajfert, Jaroslav. „Pjesma“. [ In:] Ašanin, Miodrag. Zvona sunca i grobova. Zagreb: Lykos, 1958, 113-114.

Sajfert, Jaroslav. „Pesma“. [ In:] Jara Ribnikar, Desanka Maksimović (izbor i prevod). Savremena čehoslovačka poezija. Beograd: Nolit, 1962, 86.

Seifert, Jaroslav. Město v slzách, Samá láska, Svatební cesta, Slavík zpívá špatně, Poštovní holub. Praha:

Československý spisovatel, 1989. 
Aleksandra Korda-Petrović

\section{POEMS OF JAROSLAV SAJFERT TRANSLATED BY MIODRAG SIBINOVIC}

\section{Summary}

It is less known that in the rich volume of literary translations of Professor Miodrag Sibinovic (1937-2020) there are translations of verses of the Czech poet Jaroslav Sajfert, Nobel Prize recipient for literature. The translations of ten poems of the Czech poet were published in the Mostovi journal in 1985, followed by a text of Professor Dragutin Mirković, entitled "At the CrossroadsCrossways between Proletarian Poetry, Poetism and Traditionalism", in which the development of the poet's poetics was studiously perceived. Among the translated poems there are also those translated from the Czech language by other outstanding translators, but we can read some of them today only in the translation of Miodrag Sibinović. We can perceive the quality of these translations not only in the translator's knowledge and experience, but first of all, in his personal poetic talent by means of which he succeeded in presenting the spirit and beauty of Jaroslav Sajfert's poetry.

Keywords: Miodrag Sibinovic, translation of poetry, Jaroslav Sajfert. 